\title{
Research on Comprehensive Evaluation of Military Aircrafts' Overhaul Performance Based on Entropy Weight and Cloud Model
}

\author{
Zhang Lei ${ }^{1}$, Jing Yachao*2 \\ ${ }^{1}$ Equipment Management and UAV Engineering College, Air Force Engineering University, Xi'an, China \\ ${ }^{2}$ Equipment Management and UAV Engineering College, Air Force Engineering University, Xi'an, China
}

\begin{abstract}
Due to the complex evaluation of the current military aircrafts' overhaul performance with many influencing factors, an evaluation index system of military aircrafts' overhaul performance was constructed. It was proposed that the entropy weight method (EWM) was used to calculate the performance results, and then the performance of the reliability and validity of the results was verified based on the cloud model. By collecting the performance index data of a certain type of military aircraft overhaul from 2015 to 2018, the value of the overhaul performance of this type of military aircraft was calculated, and the feasibility and effectiveness of the method were verified.
\end{abstract}

\section{Introduction}

The overhaul of military aircraft refers to the repair of the aircraft in accordance with technical standards to fully restore its technical state, which is the highest level of aircraft equipment and the most complex repair [1]. The overhaul of military aircraft has always attracted attention from the theoretical research field and the practical field. Judging from the current academic research results, scholars have carried out some research on the evaluation of maintenance capabilities on equipment base-level, the evaluation of overhaul capabilities of Chinese main aircrafts and the efficiency of military aircraft overhauls. However, most of them are considered from the specific overhaul process rather than the combination of actual situation of the overhauled factories. At the same time, owing to the complicated, professional and high-tech overhaul process of military aircraft [2], how to scientifically evaluate the performance of military aircraft overhaul is of great significance for improving the combat capability of equipment and quickly forming combat effectiveness. Among them, how to scientifically determine the weights between performance indicators to avoid the influence of subjective factors, is a key factor that needs to be resolved in the performance evaluation of military aircraft overhaul [3]

There are many methods for determining weights at present. The analytic hierarchy process has advantage over other methods, and has good applicability in solving difficult program selection, decision-making and evaluation problems [4]. However, it is not easily convincing due to the many qualitative components. The Delphi method concentrates the thoughts of experts, while it is time-consuming and labor-intensive [5]. Some scholars use the gray correlation degree to determine the weight when evaluating the progress management of military model R\&D projects [6], while it is too subjective. Compared with subjective weighting methods such as Delphi method and analytic hierarchy process, entropy weight method is a relatively objective weighting method [7], which can better illustrate the results. The cloud model can use the cloud generation algorithm to calculate the cloud digital feature parameters and generate a sufficient number of cloud drops [8] to reflect the distribution characteristics of the research object, which is used as a method to verify the reliability and validity of evaluation results.

In view of this, this research aims at the actual status of the current military aircraft overhaul, and plans to combine the overhaul process of military aircraft and the actual capacity building of the overhaul factory to scientifically construct an evaluation index system of military aircrafts' overhaul performance. The entropy weight method is used to determine the weights between the evaluation indicators, thereby establishing an evaluation model of military aircrafts' overhaul performance, and by introducing the cloud model to test the reliability and validity of performance evaluation of the military aircrafts' overhaul. Finally, taking a certain type of military aircraft as an example, the evaluation of its overhaul performance has verified the scientificity and rationality of the method.

\section{Construction of Performance Index System for Military Aircraft Overhaul}

According to the overhaul procedures and requirements of military aircraft specified by GJB3969-2000, the overhaul

*e-mail: jyc9409@163.com 
procedures include receiving in the factory, comprehensive inspection, disassembly, cleaning, repair or replacement, final assembly, debugging, flight test, delivery and delivery, etc. From the perspective of the mechanism process of performance formation, it is not only affected by the "hard" factors such as equipment, spare parts, technology, and capabilities, but also by the "soft" factors of management such as human resources, quality, schedule, and cost. Therefore, this study combines the actual conditions of the current overhaul factory of military aircraft, adopts the balanced scorecard (BSC) model and key performance indicators and other theories to clarify that the five aspects of finance, service force, quality and safety, overhaul internal process and overhaul technical capabilities will have an impact on the performance of military aircraft overhaul.

The cost of military aircraft overhaul mainly considers factors such as the cost of a single overhaul, the financial efficiency of the overhaul factory, and the operating status of assets. The service of the troops is mainly reflected by their satisfaction with the factories and the number of aircraft continuously sent for repairs. Quality and safety are mainly considered from the perspective of the effects of military aircraft overhauls, and are reflected from repair rate, error rate, and pass rate. The internal process of the overhaul mainly reflects the management of the military aircraft overhaul project, which is measured from the aspects of overhaul cycle management, equipment supply, aircraft equipment, etc. Technical capabilities of overhaul are measured from innovation investment of plant, informatization construction, and human resource management.

Based on the influencing factors of military aircrafts' overhaul performance proposed from overhaul procedures and processes and the capacity of overhaul factory, this study identified five first-level indicators of performance evaluations of military aircraft overhaul from finance, that is, service forces, quality and safety, overhaul internal processes, and overhaul technical capabilities., and further refined into 30 second-level indicators that can be quantified, so as to construct an evaluation index system of military aircrafts' overhaul performance with a reasonable structure and a complete system has been constructed, as shown in Table I.

Table1. Index system of performance evaluation for military aircraft overhaul

\begin{tabular}{|c|c|c|c|}
\hline $\begin{array}{c}\text { First-level } \\
\text { indicators }\end{array}$ & \multicolumn{3}{|c|}{ Second-level indicators } \\
\hline Finance & $\begin{array}{c}\text { single vehicle } \\
\text { overhaul cost }\end{array}$ & asset turnover & $\begin{array}{c}\text { current assets } \\
\text { turnover rate }\end{array}$ \\
\cline { 2 - 4 } & $\begin{array}{c}\text { cost } \\
\text { performance } \\
\text { index }\end{array}$ & $\begin{array}{c}\text { return on total } \\
\text { assets }\end{array}$ & $\begin{array}{c}\text { overhaul } \\
\text { progress } \\
\text { performance } \\
\text { index }\end{array}$ \\
\cline { 2 - 4 } & return on & & \\
\hline $\begin{array}{c}\text { Troop } \\
\text { service }\end{array}$ & service times & satisfaction rate & $\begin{array}{c}\text { share increase } \\
\text { rate }\end{array}$ \\
\hline Quality & repair rate & $\begin{array}{c}\text { error rate } \\
\text { (Mechanical } \\
\text { failure) }\end{array}$ & $\begin{array}{c}\text { special } \\
\text { inspection } \\
\text { pass rate }\end{array}$ \\
& & $\begin{array}{c}\text { monthly } \\
\text { inspection pass } \\
\text { rate }\end{array}$ & $\begin{array}{c}\text { one pass } \\
\text { inspection rate }\end{array}$ \\
\cline { 2 - 4 } & error rate \\
& (human failure) & \multicolumn{2}{c}{} \\
\hline
\end{tabular}

\begin{tabular}{|c|c|c|c|}
\hline \multirow{4}{*}{$\begin{array}{l}\text { Overhaul } \\
\text { internal } \\
\text { process }\end{array}$} & $\begin{array}{l}\text { flight test pass } \\
\text { rate }\end{array}$ & seat Occupancy & $\begin{array}{l}\text { equipment } \\
\text { utilization }\end{array}$ \\
\hline & $\begin{array}{c}\text { overdue rate of } \\
\text { overhaul time }\end{array}$ & $\begin{array}{l}\text { overdue rate of } \\
\text { factory time }\end{array}$ & $\begin{array}{l}\text { working hours } \\
\text { utilization }\end{array}$ \\
\hline & repair rate & completion rate & $\begin{array}{c}\text { on-time arrival } \\
\text { rate of } \\
\text { equipment } \\
\text { orders } \\
\end{array}$ \\
\hline & $\begin{array}{c}\text { inventory } \\
\text { equipment } \\
\text { turnover rate }\end{array}$ & & \\
\hline \multirow[t]{2}{*}{$\begin{array}{c}\text { Overhaul } \\
\text { technical } \\
\text { ability }\end{array}$} & $\begin{array}{c}\text { job } \\
\text { competency } \\
\text { rate } \\
\end{array}$ & $\begin{array}{c}\mathrm{R} \& \mathrm{D} \\
\text { expenditure }\end{array}$ & $\begin{array}{l}\text { training } \\
\text { expenditure }\end{array}$ \\
\hline & $\begin{array}{l}\text { IT spending } \\
\text { percentage }\end{array}$ & & \\
\hline
\end{tabular}

\section{Construction of Performance Evaluation Model for Military Aircraft Overhaul}

Considering that subjective evaluation methods have strong subjectivity and unconvincing results, this study proposes the idea of constructing a performance evaluation model of military aircraft overhaul based on entropy weight method and cloud model. Firstly, it collects historical index data and standardizes the evaluation index based on the constructed military aircraft overhaul performance. Secondly, it uses the entropy weight method to determine the weight of the evaluation index system, and finally verifies the reliability and validity of the evaluation results based on the cloud model.

\subsection{Basic Principles of Entropy Weight Method}

The basic idea of the entropy weight method is to objectively determine the weight based on the variability of the index. The smaller information entropy $E_{j}$ of an indicator is, the greater the variation of the indicator value, the more information entropy provided. The greater its role in evaluation, the greater its weight. On the contrary, the weight is smaller. The calculation formula of the entropy method is as follows [9].

The first one step is to standardize data.

Standardize the collected index data. There are $\mathrm{k}$ indicators $Z_{1}, Z_{2}, \ldots, Z_{k}$, where $Z_{i}=\left\{Z_{1}, Z_{2}, \ldots\right.$, $\left.Z_{k}\right\}$. The value of each indicator data is standardized as

$$
\mathrm{B}_{\mathrm{ij}}=\frac{Z_{\mathrm{ij}}-\min \left(Z_{i}\right)}{\max \left(Z_{i}\right)-\min \left(Z_{i}\right)} \text {. }
$$

The second step is to evaluate the information entropy of each index.

According to the definition of information entropy, there are

$$
\begin{gathered}
E_{j}=-\ln (\mathrm{n})^{-1} \sum_{i=1}^{n} p_{\mathrm{ij}} \ln p_{\mathrm{ij}}, \\
\text { where } p_{\mathrm{ij}}=\frac{\mathrm{B}_{\mathrm{ij}}}{\sum_{i=1}^{n} \mathrm{~B}_{\mathrm{ij}}} \text {; if } p_{\mathrm{ij}}=0 \text {, then, } \lim _{p_{\mathrm{ij} \rightarrow \infty}} p_{\mathrm{ij}} \ln p_{\mathrm{ij}}=0
\end{gathered}
$$

The third step is to determine the weight of each indicator.

According to Formula (2), the information entropy weight of $E_{1}, E_{2}, \ldots E_{k}$ can be calculated. 


\subsection{Evaluation results}

According to the constructed performance evaluation index system of military aircraft overhaul, the data of each index is collected, and the weight of each index is determined by the entropy weight method. Therefore, the calculation formula of performance evaluation of the military aircraft overhaul is

$$
\mathrm{M}=\sum_{i=1}^{k} \omega_{i} K_{i}(\mathrm{i}=1,2 \ldots, \mathrm{k}),
$$

where $K_{i}$ is the performance evaluation index value of military aircraft overhaul.

\subsection{Reliability and Validity Test}

In the cloud model, expected value of $E_{x}$ is the most representative digital feature, which is the average of all quantified values after qualitative concept conversion. Entropy $E_{n}$ is used to measure the granularity of qualitative concepts, and to express the degree of ambiguity of qualitative concepts. The greater the entropy, the more ambiguous the qualitative concept, and the greater the degree of dispersion of the cloud image. Hyperentropy $H_{e}$ is a measure of the uncertainty of entropy, which can better reflect the stability of the index, that is, it can reflect the degree of condensation of cloud drops in the cloud graph ${ }^{[10]}$. The specific calculation formulae are as shown in Formulae (4) (6).

$$
\begin{gathered}
E_{x}=\frac{1}{\mathrm{n}} \sum_{\mathrm{i}=1}^{\mathrm{n}} \mathrm{x}_{\mathrm{i}}, \\
\mathrm{E}_{\mathrm{n}}=\sqrt{\frac{\pi}{2}} \times \frac{1}{\mathrm{n}} \sum_{\mathrm{i}=1}^{\mathrm{n}}\left|\mathrm{x}_{\mathrm{i}}-\mathrm{E}_{\mathrm{x}}\right|,
\end{gathered}
$$

$$
\mathrm{H}_{\mathrm{ej}}=\sqrt{\left|\mathrm{S}^{2}-\mathrm{E}_{\mathrm{n}}^{2}\right|} \text {, where } \mathrm{S}^{2}=\frac{1}{\mathrm{n}-1} \sum_{\mathrm{i}=1}^{\mathrm{n}}\left(\mathrm{x}_{\mathrm{i}}-\mathrm{E}_{\mathrm{x}}\right)^{2} \text {. }
$$

Based on this, the main distribution characteristics of the performance value can be observed by drawing a cloud map through digital features, and then verify the reliability and validity of performance evaluation results of the military aircraft overhaul.

\section{Examples}

This paper collects the data of performance indicator system of a certain type of military aircraft overhaul from 2015 to 2018. Based on Formula (1), the data is standardized, as shown in Table 3. Due to space reasons, only some indicator values are listed. Table II.

Table2. Information Entropy of Each Index

\begin{tabular}{|c|c|c|c|c|c|}
\hline $\begin{array}{c}\text { First-level } \\
\text { index }\end{array}$ & second-level index & $\mathbf{2 0 1 5}$ & $\mathbf{2 0 1 6}$ & $\mathbf{2 0 1 7}$ & $\mathbf{2 0 1 8}$ \\
\hline \multirow{4}{*}{ finance } & $\begin{array}{c}\text { Single vehicle } \\
\text { overhaul cost }\end{array}$ & 0.00 & 1.00 & 1.00 & 0.00 \\
\cline { 2 - 6 } & Asset turnover & 0.00 & 0.31 & 0.75 & 1.00 \\
\cline { 2 - 6 } & $\begin{array}{c}\text { current assets } \\
\text { turnover rate }\end{array}$ & 0.00 & 0.33 & 0.78 & 1.00 \\
\cline { 2 - 6 } & $\begin{array}{c}\text { Overhaul progress } \\
\text { performance index }\end{array}$ & 0.00 & 0.38 & 0.63 & 1.00 \\
\hline$\vdots$ & $\vdots$ & $\vdots$ & $\vdots$ & $\vdots$ & $\vdots$ \\
\hline
\end{tabular}

Using Formula (2), the information entropy of each index $\mathrm{E}_{1} \sim \mathrm{E}_{30}$ can be calculated in Table III. comprehensive weight relative to the task.

Table3. Information entropy of each index

\begin{tabular}{|c|c|c|c|c|c|c|c|c|c|c|}
\hline$E_{1} \sim E_{10}$ & 0.20 & 0.30 & 0.30 & 0.30 & 0.00 & 0.18 & 0.32 & 0.32 & 0.00 & 0.32 \\
\hline$E_{11} \sim E_{20}$ & 0.20 & 0.00 & 0.00 & 0.29 & 0.31 & 0.30 & 0.20 & 0.30 & 0.30 & 0.28 \\
\hline$E_{21} \sim E_{30}$ & 0.22 & 0.31 & 0.32 & 0.31 & 0.29 & 0.31 & 0.28 & 0.20 & 0.20 & 0.20 \\
\hline
\end{tabular}

Using formula (3), the weight of each index $\omega_{1} \sim \omega_{30}$ can be calculated, as shown in Table IV.

Table4. The weight value of each indicator

\begin{tabular}{|c|c|c|c|c|c|c|c|c|c|c|}
\hline$\omega_{1} \sim \omega_{10}$ & 0.03 & 0.03 & 0.03 & 0.30 & 0.04 & 0.04 & 0.03 & 0.03 & 0.04 & 0.03 \\
\hline$\omega_{11} \sim \omega_{20}$ & 0.03 & 0.04 & 0.04 & 0.03 & 0.03 & 0.03 & 0.03 & 0.03 & 0.03 & 0.03 \\
\hline$\omega_{21} \sim \omega_{30}$ & 0.03 & 0.03 & 0.03 & 0.03 & 0.03 & 0.03 & 0.03 & 0.03 & 0.03 & 0.03 \\
\hline
\end{tabular}

Finally, the performance evaluation value of a certain type of military aircraft overhaul from 2015 to 2018 can be calculated using formular (4), as shown in Table V.

Table5. Performance evaluation value of a certain type of military aircraft overhaul

\begin{tabular}{|c|c|c|c|c|}
\hline Year & $\mathbf{2 0 1 5}$ & $\mathbf{2 0 1 6}$ & $\mathbf{2 0 1 7}$ & $\mathbf{2 0 1 8}$ \\
\hline Performance score & 70.17 & 75.87 & 84.22 & 88.05 \\
\hline
\end{tabular}

At the same time, the cloud model from 2015 to 2018 is drawn, as shown in Figure 1. 


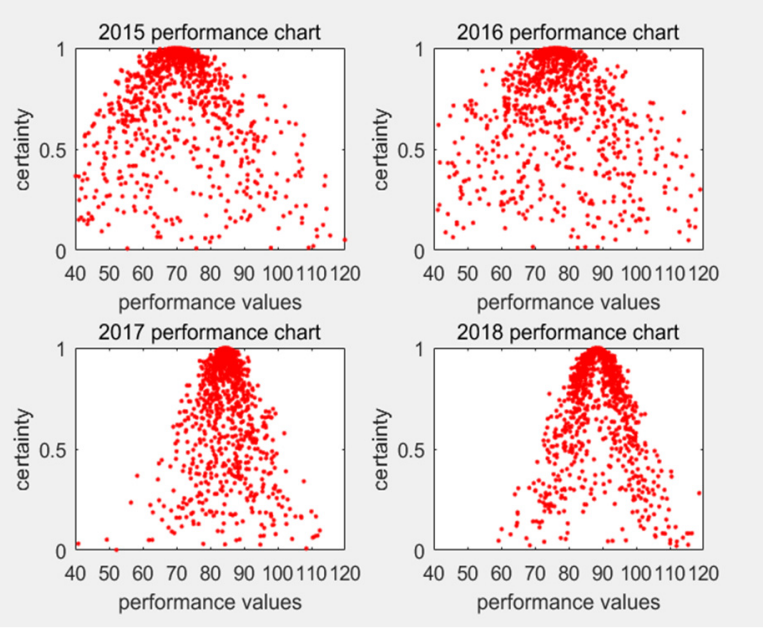

Fig 1. the performance value of a certain military aircraft overhaul from 2015 to 2018

As Figure 1 shows, the expected range of performance scores in 2015 and 2016 is basically between 70 and 80 . The degree of cloud drop aggregation is relatively scattered, with large uncertainty, indicating that the performance of a certain type of military aircraft overhaul needs to be promoted in the past two years. However, cloud drop has a higher degree of cohesion in 2017 and 2018 , with the performance expectation range basically distributed between 80 and 90 points. The performance value expectation in 2018 is closer to 90 points, which indicates that a certain type of military aircraft overhaul performance has been significantly improved. All in all, the performance value from 2015 to 2018 shows an upward trend, with the score distribution basically consistent with the results calculated by the above entropy weight method, which also verifies the effectiveness and feasibility of the entropy weight method in the performance evaluation of military aircraft overhaul.

\section{5 conclusion}

The performance of military aircraft overhaul is an important content that reflects the status of overhaul, and is also a research point that is highly concerned by the practice and academic circles. Therefore, according to the military aircraft overhaul procedures and the actual operation of the overhaul factory, a performance evaluation index system of military aircraft overhaul was constructed, the entropy weight method was proposed to calculate the performance evaluation results of military aircraft overhaul, the reliability and validity of the performance evaluation results were verified, based on the cloud model. Through case analysis, the method is proved to be scientific and reasonable, which can be used to carry out performance evaluation activities of military aircraft overhaul, and has strong application value in promoting overhaul performance of military aircraft.

\section{References}

1. Chinese Air Force Encyclopedia Editing Committee. Chinese Air Force Encyclopedia [M]. Beijing: Aviation Industry Press, 2005.

2. Meng Ke, Zhang Hengxi, Meng Manli. Comprehensive Evaluation and Decision-making Model of Fighter Model Engineering Based on Rough Set [J]. Acta Aeronautica Sinica, 2006, (04): 641-645.

3. Ni Zichun, Di Peng, Wang Xuan. Evaluation method of equipment design scheme based on cloud model [J]. Ordnance Equipment Engineering Journal, 2020, (05): 227-233.

4. Ma Xuejun, Zhang Huaiqiang, Cheng Yingrui. Fuzzy evaluation and decision-making on the economics of ship equipment demonstration program [J]. Ship Science and Technology, 2014, (07): 146-149.

5. $\mathrm{Xu}$ Bing, Bai Xiao. Project Risk Identification, Measurement and Evaluation Research Review [J]. Project Management Technology, 2014, (05): 25-28.

6. Chang Sheng, Xue Huifeng. Fuzzy Comprehensive Evaluation Model of Military Model Development Project Progress [J]. Enterprise Management, 2011, (06): 183-185.

7. Wang Chongchong. Analysis of Influencing Factors of Project Cost Based on Entropy Weight-Fuzzy Comprehensive Evaluation [D]. Master's thesis of Anhui University of Science and Technology, 2019.

8. Liu Dunwen, Cao Min, Tang Yu, Xu Qian, Jiang Bing, Wang Fangli. Water-rich Karst Tunnel Gushing Risk Assessment Based on Cloud Model [J]. China Work Safety Science and Technology, 2021, (17): 109-115.

9. Li Xiaoying, Lu Jianxia, Dong Qiaoying. Analysis Method of Customer Requirements for Projectoriented Manufacturing Enterprises $[\mathrm{J}]$. Light Industry 